\title{
Advanced Access in Primary Health Care: experiences from Brazil and Canada
}

\author{
Acesso Avançado na Atenção Primária à Saúdle: experiências do Brasil e Canadá \\ Acceso Avanzado en Atención Primaria de Salud: experiencias de Brasil y Canadá
}

Received: 12/01/2021 | Reviewed: 12/06/2021 | Accept: 12/10/2021| Published: 12/18/2021

Isabela Oliveira de Almeida

ORCID: https://orcid.org/0000-0002-7517-0827 Universidade Estadual de Campinas, Brasil

E-mail: isaa.almeida07@gmail.com

Débora de Souza Santos

ORCID: https://orcid.org/0000-0001-9060-3929

Universidade Estadual de Campinas, Brasil

E-mail:deborass@unicamp.br

Dalvani Marques

ORCID: https://orcid.org/0000-0002-4136-2564 Universidade Estadual de Campinas, Brasil

E-mail: dalvani@unicamp.br

Fernanda Mota Rocha

ORCID: https://orcid.org/0000-0002-3820-6691 Universidade Estadual de Campinas, Brasil

E-mail: fmrocha01@gmail.com

Nathalia de Souza Monezi

ORCID: https://orcid.org/0000-0002-5584-9023 Universidade Estadual de Campinas, Brasil

E-mail: nathaliamonezi@gmail.com

\begin{abstract}
Access is the timely use of services in order to meet the needs of the user. As an alternative to the traditional model, the Advanced Access (AA) model appears in Canada, with schedules restricted to specific cases. Objectives: The purpose of this article is to analyze the existing scientific production about the Advanced Access model in Primary Health Care. Methods: Integrative literature review using the descriptors (1) "Health Care Accessibility" OR "Primary Health Care" AND and (2) "Advanced Access" in the PubMed, Scopus and BIREME databases. Selection criteria were studies published in the last five years, available in Portuguese, English or Spanish and dealing with the theme. Results: Eight studies were selected, six were grouped into two categories of analysis: "The Canadian experience with AA : a model in consolidation"; and "The Brazilian experience with AA: local experiments" and the other two contributed to enrich the discussion. The AA stands out to balance capacity and demand with physical infrastructure and adequate staff, both in the international arena, as the experiences of municipalities, improving the quality of APS. Conclusion: Studies that detail the AA in its practice, as well as the challenges and needs, can inspire other health units to study it and consider its implementation if it is appropriate for its context, aiming to improve the health and care of its population.
\end{abstract}

Keywords: Nursing; Nursing team; Primary health care; Access to health services; Workflow.

\section{Resumo}

Acesso é a utilização oportuna de serviços para atender às necessidades do usuário. Como alternativa ao modelo tradicional, surge no Canadá o modelo Acesso Avançado (AA), com horários restritos a casos específicos. Objetivo: o objetivo deste artigo é analisar a produção científica existente sobre o modelo de Acesso Avançado na Atenção Básica à Saúde. Métodos: Revisão integrativa da literatura utilizando os descritores (1) "Health Care Accessibility" OR "Primary Health Care" AND e (2) "Advanced Access" nas bases de dados PubMed, Scopus e BIREME. Os critérios de seleção foram publicados nos últimos cinco anos, disponíveis em português, inglês ou espanhol e abordando a temática. Resultados: Oito estudos foram selecionados, seis foram agrupados em duas categorias de análise: "A experiência canadense com AA: um modelo em consolidação"; e "A experiência brasileira com AA: experiências locais" e as outras duas contribuíram para enriquecer a discussão. O AA se destaca por equilibrar capacidade e demanda com infraestrutura física e quadro de pessoal adequado, tanto no cenário internacional, quanto nas experiências dos municípios, melhorando a qualidade da APS. Conclusão: Estudos que detalham o AA em sua prática, bem como os desafios e necessidades, podem inspirar outras unidades de saúde a estudá-lo e considerar sua implantação se for adequado ao seu contexto, visando melhorar a saúde e o cuidado de sua população.

Palavras-chave: Enfermagem; Equipe de enfermagem; Atenção Primária à Saúde; Acesso aos serviços de saúde; Fluxo de trabalho. 


\section{Resumen}

El acceso es el uso oportuno de los servicios para satisfacer las necesidades del usuario. Como alternativa al modelo tradicional, el modelo de Acceso Avanzado (AA) aparece en Canadá, con horarios restringidos a casos específicos. Objetivos: El propósito de este artículo es analizar la producción científica existente sobre el modelo de Acceso Avanzado en Atención Primaria de Salud. Métodos: Revisión integrativa de la literatura utilizando los descriptores (1) "Accesibilidad a la atención médica" O "Atención primaria de salud" Y y (2) "Acceso avanzado" en las bases de datos PubMed, Scopus y BIREME. Los criterios de selección fueron estudios publicados en los últimos cinco años, disponibles en portugués, inglés o español y que trataran el tema. Resultados: Se seleccionaron ocho estudios, seis se agruparon en dos categorías de análisis: "La experiencia canadiense con AA: un modelo en consolidación"; y "La experiencia brasileña con AA: experimentos locales" y los otros dos contribuyeron a enriquecer la discusión. La AA se destaca por equilibrar capacidad y demanda con infraestructura física y personal adecuado, tanto en el ámbito internacional, como en las experiencias de los municipios, mejorando la calidad de APS. Conclusión: Los estudios que detallan el AA en su práctica, así como los desafíos y necesidades, pueden inspirar a otras unidades de salud a estudiarlo y considerar su implementación si es apropiado para su contexto, con el objetivo de mejorar la salud y la atención de su población.

Palabras clave: Enfermería; Equipo de enfermería; Atención Primaria de Salud; Acceso a los servicios de salud; Flujo de trabajo.

\section{Introduction}

Primary Health Care (PHC), through the Family Health Strategy, after a long historical process in Brazil is consolidated as the user's first contact with the Health Care Network of the Unified Health System (SUS). Primary Care, according to its National Policy, is defined as a set of diagnostic, protective, curative and health promotion actions, with the objective of developing comprehensive care contextualized to the health situation of communities (Brazil 2017).

For this, in Brazil, the Family Health team must act within the population through a work in multidisciplinary team des involves $g$ are and care practices with health responsibility targeted to this population and specific territories and its peculiarities. The Family Health Strategy and its continuous care become essential parts for the reaffirmation and execution of the SUS principles: universality, equity and integrality (Brasília 2000; Belo Horizonte 2010).

According to Starfield (2002), access is defined as the timely use of services in order to meet the needs of the user. The access model traditionally used to offer health services is based on dividing care into two categories: urgent and non-urgent. The user arrives at the health service and undergoes a screening with a professional. In this screening, the degree of urgency of that individual's situation is defined, which will be directed to reception with a nurse or doctor. The patients who have a condition classified as urgent are not scheduled for some future time with programmatic service (Vidal 2013).

This model is criticized in the work of Murray and Tantau (2000) for generating an accumulation of work and, consequently, a long queue for scheduled appointments. Another consequence is the high rate of absences in consultations, due to the delay in scheduling, the user ends up forgetting it or having his problem "solved" before it arrives. The patient admitted on the spot for having an acute complaint considered urgent also faces problems in the traditional model: in care, only his main complaint will be addressed and investigated. Other essential demands, however considered non-urgent, are scheduled and postponed, limiting comprehensive care (Vidal 2013).

As an alternative to the traditional PHC access model, the Advanced Access (AA) model emerges for the reconstruction of the scheduling system for a saturated service in northeastern California, in 1990 (Vidal 2013). The AA has the principle of "doing the job today, today", seeking to balance the demand of patients with the supply of health professionals who provide care. This means that the patient que will get your problem resolved on the same day Quality and seeks r the service, is your urgent case, routine or preventive (Vidal 2013).

In this way, scheduling becomes restricted to prenatal care and childcare, for example, and will be carried out on less busy days due to spontaneous demands. The rest of the agenda, which previously served to deal with less urgent cases, will aim to make consultations available for spontaneous demand regardless of the case. Consultations should take around 15 to 20 
minutes to avoid overloading the service and a long queue (Gonçalves 2018; Wollmann 2014) .

The AA offers the following advantages pointed out by the literature: abolition of long queues for a scheduled appointment; drop in the high level of absenteeism in consultations, making them more effective; users more satisfied with the feeling of resolutive health care; decrease in user anxiety for the service with a real possibility of decreasing demand, allowing the team to dedicate more time to other health management and education actions (Gonçalves 2018; Wollmann 2014). However, the change in the type of access should not mean the decay of care. There is a possibility for a PHC service to focus on complaintconduct, reproducing the biomedical model, with an emphasis on medicalizing processes to the detriment of comprehensive and contextualized care to the social determinants and conditions of health.

For the correct operation of the AA model, it is necessary that it be implemented in an adequate and proportional way to the needs and resources of the health unit and in accordance with the current health policy. There is not much evidence of the implementation of AA and its relationship with the work process of the health team.

In view of this situation and the potential of AA in the reconfiguration of the model of access to care in PHC, an integrative literature survey was necessary to systematize the current knowledge on the subject and obtain a better understanding of the AA model (s) experienced in Brazil and in the world. Therefore, the objective of this article is to analyze the existing scientific production about the Advanced Access model in Primary Health Care.

\section{Methodology}

This study had the methodological strategy of conducting an integrative review, which seeks a complete understanding of the phenomenon analyzed, providing a synthesis of knowledge on the subject so that it is possible to apply the results of significant studies in practice (Souza 2010). This literature review method contemplates the so-called Evidence-Based Practice (EBP), which is characterized as a care and teaching approach based on scientific evidence produced by studies that answer a specific question or phenomenon (Souza 2010).

In the first phase of the integrative review, the guiding question of the research was elaborated. For the formulation, the PICO strategy (was used Patient, Intervention, Comparison and " The Outcomes " [outcome]) (Santos 2007), in which it was considered: P - health professionals APS; I: implementation / development of Advanced Access in PHC; C: experiences from different contexts; O: evaluation of the implementation / development of Advanced Access.

The application of the PICO strategy enabled the definition of the question: "What is the scientific production present in the literature about the experiences of implementing the Advanced Access model in PHC?".

The second phase involved the search and sampling of literature in databases, so that the sampling criteria guaranteed reliable results that answered the study question and added knowledge to the discussion (Souza 2010).

To search for the articles, the descriptors of the Medical Subject Headings (MeSH) were selected. Combinations were made between the four descriptors selected as a search strategy using the Boolean operators "(OR)" and "(AND)" aiming at more significant results: (1) "Health Care Accessibility" OR "Primary Health Care" AND and (2) "Advanced Access". The collection of studies was carried out in the databases Medline (search engine PubMed), SciVerse Scopus (Scopus) and Lilacs (through the Regional Portal of the Virtual Health Library - BIREME). Selection criteria were studies published in the period 2015 - 2020 (last five years, due to the scarcity of studies in later periods), available in Portuguese, English or Spanish and dealing with the theme. 
Figure 1: Flowchart of constitution of the sample.

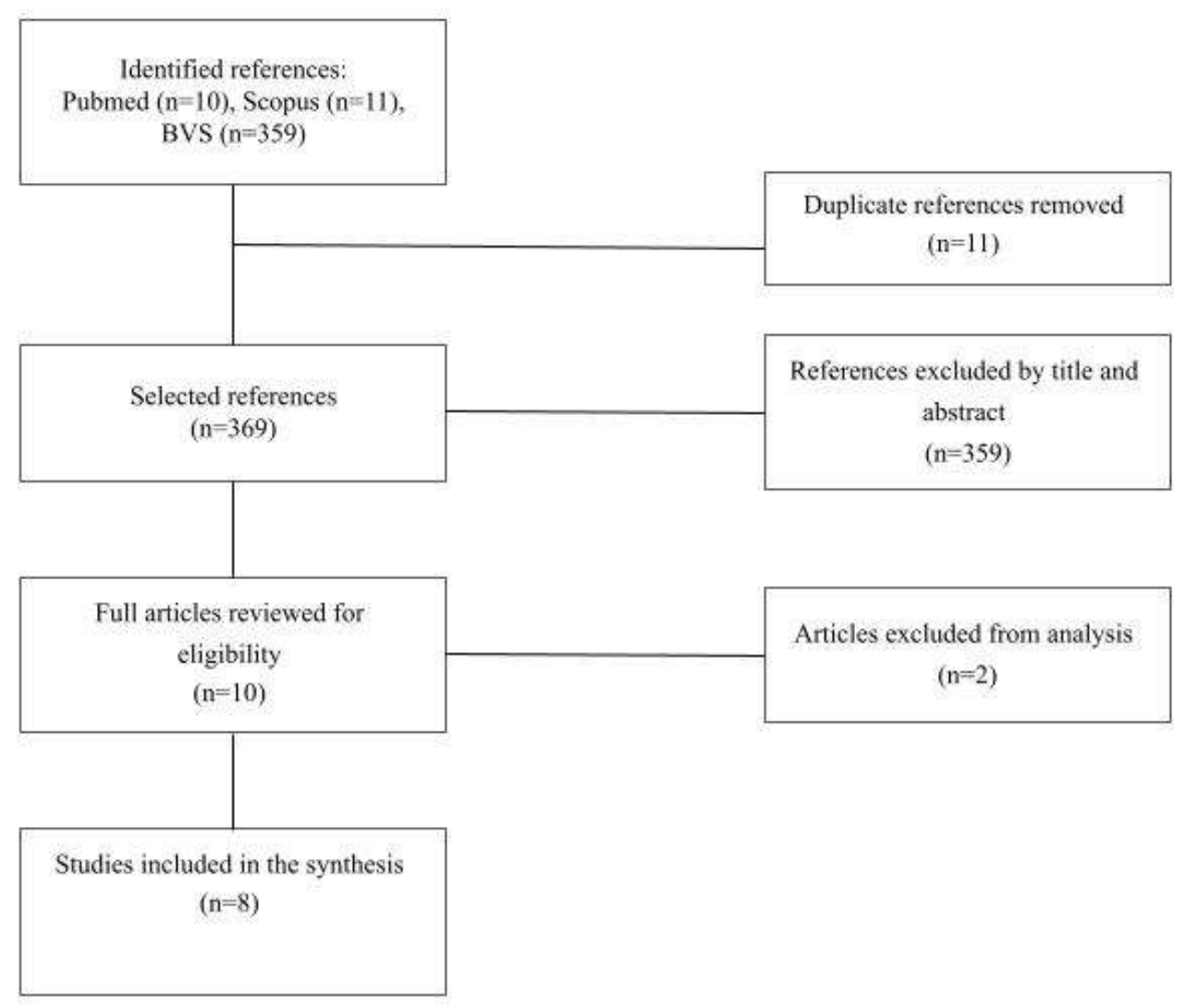

Source: Own elaboration.

In the third and fourth phase of the review, data were extracted from the eight selected studies in order to assess the scientific rigor (Souza 2010, Santos 2007), the characteristics and the practical usefulness of each study, through a specific instrument for collecting the information: subjects, AA implementation methodology and results of the experiment .

The fifth phase of the integrative review was the discussion of the results, encompassing the comparison of the data found in the analysis of the studies. Common points and differences in the results of the studies were highlighted, thus being able to interpret and discuss them, in addition to listing the needs for new research based on the observed knowledge gaps. The findings were summarized and organized to favor the comparison of studies on specific topics (Souza 2010). In this process, the presentation of the results and discussion of the review were organized into two categories of analysis: "The Canadian experience with AA: a model in consolidation"; and "The Brazilian experience with AA: local experiments". Each analysis category made it possible to deepen the knowledge about different AA experiences in PHC from disparate countries, but which have political and strategic similarities in the configuration of Primary Health Care.

\section{Results and Discussion}

As shown in Figure 1, eight (8) studies were selected between the years 2015 and 2020, with a predominance of Scopus. As for the methodology used, there was a predominance of studies with a qualitative approach (5), followed by a quantitative approach (2) and a literature review (1). The studies were carried out and published in Brazil (5) and Canada (3). 
The six (6) studies on AA implantation / development experiences in PHC services were grouped into two categories of analysis: "The Canadian experience with AA: a model in consolidation" ; and "The Brazilian experience with AA: local experiments". The other two studies contributed to enrich the discussion about Brazilian and Canadian experiences.

Table 1: Identification of articles, according to authorship, year of publication, objective, method and main results.

\begin{tabular}{|c|c|c|c|c|}
\hline & Author / Journal / Country & Objective & Methodology & Main results of \\
\hline & \multicolumn{4}{|c|}{ CANADIAN EXPERIENCE } \\
\hline 1 & $\begin{array}{l}\text { Sabina Abou Malham, Nassera } \\
\text { Touati, Lara Maillet, Isabelle } \\
\text { Gaboury, } \\
\text { Christine Loignon, and } \\
\text { Mylaine Breton } \\
\text { International Journal of Family } \\
\text { Medicine } \\
\text { Canada, } 2017\end{array}$ & $\begin{array}{l}\text { Analyze the principles of } \\
\text { AA implemented in a } \\
\text { Basic Health Unit and } \\
\text { identify which factors } \\
\text { influenced the } \\
\text { implementation. }\end{array}$ & $\begin{array}{l}\text { Multiple case study of } 4 \\
\text { selected units. }\end{array}$ & $\begin{array}{c}\text { Structural and organizational factors facilitated } \\
\text { implementation: training employees to support } \\
\text { change, collective leadership, } \\
\text { and openness to change. On the other hand, family } \\
\text { doctors who practice in various clinical settings, lack } \\
\text { of staff resources, turnover } \\
\text { office staff, rotation of resident physicians and } \\
\text { management skills have been reported as major } \\
\text { barriers to the implementation of the } \\
\text { model. }\end{array}$ \\
\hline two & $\begin{array}{l}\text { Jennifer Fournier, Amanda } \\
\text { Rainville, Jason Ingram and } \\
\text { Roberta Heale } \\
\text { Healthcare Quarterly } \\
\text { Canada, } 2015\end{array}$ & $\begin{array}{l}\text { Submit a review of the } \\
\text { implementation of } \\
\text { scheduling access at a } \\
\text { nurse-led clinic (NPLC) } \\
\text { in northern Ontario. }\end{array}$ & $\begin{array}{l}\text { Case study and review of } \\
\text { AA implantation, } \\
\text { comparison with results } \\
\text { found in the literature. }\end{array}$ & $\begin{array}{c}\text { From the point of view of health professionals, } \\
\text { administrative staff and administrators, Advanced } \\
\text { Access has become a timely subject in primary care, } \\
\text { given the chronic } \\
\text { scarcity of services and funding constraints and the } \\
\text { need } \\
\text { for greater effectiveness. }\end{array}$ \\
\hline 3 & $\begin{array}{c}\text { Mylaine Breton, Lara Maillet, } \\
\text { Isabelle Paré, } \\
\text { Sabina Abou Malham, Nassera } \\
\text { Touati. } \\
\text { The International Journal of } \\
\text { Health Planning and } \\
\text { Management } \\
\text { Canada, 2016. }\end{array}$ & $\begin{array}{l}\text { To describe } \\
\text { the implementation of the } \\
\text { advanced access model, } \\
\text { perceived by the first } \\
\text { family doctors; } \\
\text { analyze the factors that } \\
\text { influence the } \\
\text { implementation of its } \\
\text { principles; and document } \\
\text { the } \\
\text { perceptions of doctors } \\
\text { about its effects on their } \\
\text { practice, colleagues and } \\
\text { patients. }\end{array}$ & $\begin{array}{l}\text { Qualitative methods were } \\
\text { used to explore, through } \\
\text { semi-structured } \\
\text { interviews, the } \\
\text { experiences of } 21 \text { doctors } \\
\text { who made the transition } \\
\text { to advanced access. }\end{array}$ & $\begin{array}{l}\text { When well planned, the transition from a traditional } \\
\text { practice to an advanced access practice can be } \\
\text { achieved smoothly. Individual and organizational } \\
\text { capabilities will determine what adjustments need to } \\
\text { be made during the first few months of change. The } \\
\text { involvement of all actors - not only professionals and } \\
\text { organizations, but also patients - the transition to } \\
\text { advanced access is an essential factor for success } \\
\text { Implementation. }\end{array}$ \\
\hline \multicolumn{5}{|c|}{ BRAZILIAN EXPERIENCE } \\
\hline 4 & $\begin{array}{c}\text { Lélia Fernandes de Souza, } \\
\text { Felipe Macedo Rossi, Adriano } \\
\text { Fernandes Ogera, Monica } \\
\text { Alves Borges, } \\
\text { Solange dos Santos Galdino, } \\
\text { Priscila Fernanda Zucatto } \\
\text { Bertolasse de Souza et al. } \\
\text { XXX Congress of Municipal } \\
\text { Health Secretaries of the State } \\
\text { of São Paulo - Municipal } \\
\text { Health Secretariat of São Paulo } \\
\text { Brazil, 2016. }\end{array}$ & $\begin{array}{l}\text { Describe the current } \\
\text { situation of Advanced } \\
\text { Access in the Green Team } \\
\text { of UBS / ESF Parque } \\
\text { Lapa one year after its } \\
\text { implementation, in order to } \\
\text { share the difficulties and } \\
\text { achievements of a } \\
\text { work resulting from the } \\
\text { articulation of the entire } \\
\text { team. }\end{array}$ & $\begin{array}{l}\text { Team meetings recorded } \\
\text { in the ATA book, literary } \\
\text { reviews on the topic, } \\
\text { field research with visits } \\
\text { to the unit of the same } \\
\text { Supervision that already } \\
\text { used the proposed system } \\
\text { and } \\
\text { elaboration of the } \\
\text { evaluation process } \\
\text { directed to users. }\end{array}$ & $\begin{array}{l}\text { We highlight the great commitment of the entire } \\
\text { team during the construction of this new service } \\
\text { model, the search to overcome daily difficulties and } \\
\text { paradigms, and the support received from the unit's } \\
\text { management and Technical Health Supervision. } \\
\text { good acceptance from users. After a year of work, it } \\
\text { is concluded that advanced access is a viable service } \\
\text { proposal. }\end{array}$ \\
\hline 5 & $\begin{array}{l}\text { Luís Antônio Soares Pires } \\
\text { Filho, João Mazzoncini de } \\
\text { Azevedo-Marque, Nádia } \\
\text { Santos Miranda } \\
\text { Duarte, Leonardo Moscovici. } \\
\text { Health Debate }\end{array}$ & $\begin{array}{l}\text { Report aspects of the } \\
\text { implementation of AA in a } \\
\text { Family Health Unit. }\end{array}$ & $\begin{array}{l}\text { Data collection by the } \\
\text { electronic system of the } \\
\text { city of Ribeirão Preto and } \\
\text { interview with health } \\
\text { professionals about AA. }\end{array}$ & $\begin{array}{l}\text { With the implantation of AA, absenteeism and } \\
\text { waiting days for care decreased when compared to } \\
\text { the period before implantation. Medical attendance } \\
\text { and the number of referrals increased. The team } \\
\text { considers AA beneficial to the unit. }\end{array}$ \\
\hline
\end{tabular}




\begin{tabular}{|c|c|c|c|c|}
\hline & Brazil, 2019 & & & \\
\hline 6 & $\begin{array}{c}\text { Ana Emilia Bagueira Leal; } \\
\text { Bruno Takase Watanabe; } \\
\text { Clarissa Willets } \\
\text { Heifer; Renata Alves de Souza } \\
\text { Palluello; Janos Valery } \\
\text { Gyuricza; Talita Rewa et al. } \\
\text { Regional Coordination of West } \\
\text { Health-Production - Municipal } \\
\text { Health Secretariat of São Paulo } \\
\text { Brazil, } 2016 .\end{array}$ & $\begin{array}{l}\text { The objective is to expand } \\
\text { and qualify the } \\
\text { population's access to } \\
\text { consultations for doctors. }\end{array}$ & $\begin{array}{l}\text { Comparison between the } \\
\text { patient's correspondence } \\
\text { averages by the doctor } \\
\text { seen after the change, } \\
\text { through analysis of the } \\
\text { production sheets - } \\
\text { Sheets D1- of the doctors } \\
\text { of the } \\
\text { unity. }\end{array}$ & $\begin{array}{l}\text { The increase in the number of places offered, as well } \\
\text { as the greater correspondence between the patient } \\
\text { and the care provided by the team itself, has } \\
\text { demonstrated a greater longitudinality of care, } \\
\text { representing comprehensive care, capable of serving } \\
\text { the patient in their } \\
\text { acute and chronic demands. The unit has become a } \\
\text { reference in Health for its assigned area, which now } \\
\text { seeks it even for doubts about the health system } \\
\text { itself. } \\
\text { health. }\end{array}$ \\
\hline \multicolumn{5}{|c|}{ OTHER STUDIES } \\
\hline 7 & $\begin{array}{c}\text { Suelen Alves Rocha, } \\
\text { Silvia Cristina Mangini } \\
\text { Bocchi, Moacir Fernandes de } \\
\text { Godoy. } \\
\text { Physis } \\
\text { Brazil, } 2016\end{array}$ & $\begin{array}{l}\text { Analyze the national and } \\
\text { international scientific } \\
\text { production related to the } \\
\text { increasing access to } \\
\text { primary health care. }\end{array}$ & $\begin{array}{l}\text { Integrative literature } \\
\text { review with a final } \\
\text { sample of } 16 \text { articles. }\end{array}$ & $\begin{array}{l}\text { A less wicked health system provides timely access } \\
\text { and continuity of care. Advanced access seems to be } \\
\text { the most promising scheduling model when } \\
\text { balancing demand } \\
\text { and capacity controlling the waiting time. However, } \\
\text { it is useless to modify the schedule without } \\
\text { providing the necessary structure to maintain it. }\end{array}$ \\
\hline 8 & $\begin{array}{l}\text { Tiago Barra Vidal, Suelen } \\
\text { Alves Rocha, Erno Harzheim, } \\
\text { Lisiane Hauser, } \\
\text { Charles Dalcanale Tesser. } \\
\text { Public Health Journal } \\
\text { Brazil, } 2019\end{array}$ & $\begin{array}{l}\text { Assess whether the } \\
\text { scheduling model } \\
\text { influences the user's } \\
\text { perception of the } \\
\text { quality of primary health } \\
\text { care services. }\end{array}$ & $\begin{array}{c}\text { Cross-sectional } \\
\text { population-based study }\end{array}$ & $\begin{array}{l}\text { The advanced access scheduling model had a } \\
\text { positive effect on the } \\
\text { quality of primary health care, in the users' } \\
\text { perception. }\end{array}$ \\
\hline
\end{tabular}

Source: Own elaboration.

After analyzing the studies, it was found that most of them deal with the implementation of Advanced Access in Primary Health Care (PHC) in two countries on the American continent: Brazil and Canada. Considering the entire context in which each service is inserted, each experience is unique and has its own history and challenges related to the context of PHC in each country. Therefore, we will present the experiences by country, highlighting some elements.

\section{The Canadian experience with AA: a model in consolidation}

The Canadian healthcare system, since the 1970s, has been public, with universal and comprehensive coverage. It has ten provinces and three territories, constituting thirteen different health plans, however they are intertwined by guiding principles dictated by the federal government, which guarantees more similarities than differences between them (Santos 2018).

The discussion on Primary Health Care in Canada started in the mid-1960s and crystallized with the Lalonde Report in 1974 (São Paulo 2015) . In 1978, the International Conference on Primary Health Care took place in Alma Ata, in the Republic of Kazakhstan, emphasizing the need for action to effect health promotion in the world. Thus, the first definitions of elements that would make up Primary Health Care appear, described in the Declaration of Alma Ata (WHO 1978).

Subsequently, in 1986 in the city of Ottawa, capital of Canada, PHC was consolidated at the First International Conference on Health Promotion. The focus of the conference was on health needs in industrialized countries, and the discussions were based on the progress achieved with the Alma Ata Declaration (São Paulo 2015).

In the country, all residents of each province have a health insurance card. Thus, when the population needs health care, go to the doctor or clinic of your choice. Canadian provinces must satisfy five principles (in terms of administration, coverage and organization) in order to receive full federal health transfers: public administration, coverage, universality, accessibility and transferability (Santos 2018; São Paulo 2015). 
Most doctors in Canada work in private practices, and the country does not have these professionals employed by the federal government. They are paid for services rendered, under the provincial health insurance plan. As a result, Canadians do not pay directly for the insured services of doctors and hospitals, unless they are willing to bear the full cost of services to the few doctors whose practice is entirely external to the public system. Some doctors work in community health centers, hospital clinics or outpatient services in hospitals (Santos 2018; São Paulo 2015) .

The province of Quebec, for example, has innovative actions in a provincial health system with an emphasis on the community, and is considered a reference. In this system, health establishments work in a complementary manner and are hierarchized on three levels. The Ministry of Health is located at the central level, the Health Agencies and Social Services at the regional level, and the Health and Social Services Center at the local level. These Centers serve cases of medium and high complexity in the population of their respective territory, and must guarantee access to the provision of services and assistance (Santos 2018; Brandão 2018).

Quebec was the pioneer province in Canada for the implementation of Advanced Access. The initial training of the health team is highlighted as relevant to the understanding and implementation of the model (Malham 2017; Breton 2016). In 2011 and 2012, it was provided by the Quebec Federation of General Practitioners, and the Ministry of Health and Social Services, one of the first trainings, to different categories of professionals and administrative staff, helped the team better understand the guiding principles and, in some cases, share the knowledge they have acquired with other members of their teams to effectively prepare for change (Breton 2016).

The motivation arose from the dissatisfaction expressed by patients regarding the lack of access to health services, shared by professionals, due to the long waiting lines for consultations, which led patients to seek out other doctors, generating frustration (Breton 2016).

They point out the realization of several strategies to balance the care offered by the units with the demand of the patients, with different offerings of open spaces for spontaneous demand and schedules such as $90 \%$ by $10 \%$, $65 \%$ by $35 \%$, or even $50 \%$ by $50 \%$ (Malham 2017; Breton 2016).

They also reported the assumption that not having an agenda could result in the loss of control of some patients, because in AA patients themselves are responsible for making appointments when they need it. Thus, they developed strategies from the patients ' complete autonomy to return when recommended, the monitoring of the most vulnerable through administrative data and contact with those absent for long periods of time in the units (Malham 2017).

They highlighted strategic leadership as an essential facilitator for the implementation of AA, which facilitates communication and decisions (Breton 2016), in addition to the practice shared between doctors and nurses (Malham 2017) and the improvement in collaboration between team members (Malham 2017; Breton 2016). As complicating factors, the professionals pointed out the lack of staff, whether doctors, nurses or secretaries and the resistance to changing professional roles (Malham 2017; Breton 2016)).

The orientation to the population was an essential highlight for the change in the work process with the implantation of AA, using various means available for the dissemination of the model (Malham 2017; Breton 2016).

Another study presented the implementation of AA in a Nurse-led Clinic (Nurse Practitioner-led Clinic - NPLC), which is a model of primary care with a multidisciplinary team and care focused on nursing practices, in Ontario, Canada. Opened in 2011, AA was implemented from the beginning, however, the team needed an adaptation period to adapt to the proposal (Fournier 2015).

They emphasize benefits of AA, such as patient satisfaction for having their demands met quickly, the records were better performed, the team was more satisfied, there was a reduction in absenteeism and inappropriate consultations in emergency services, in addition to better efficiency in longitudinality and continuity care (Breton 2016; Fournier 2015). 
Thus, the importance of preparing the teams to manage the challenges and adversities that may occur, such as the patient's unmet expectation when the care offer does not meet their demand and the flexibility required of the team members (Breton 2016; Fournier 2015).

\section{The Brazilian experience with AA: local experiments}

Primary Health Care had its initial experiences in Brazil around 1924 with Health Centers of the University of São Paulo (Mendes 2015), was recognized in the category of cure, prevention and health education in 1940 with the Special Public Health Service (Renovato 2010), and was extended to excluded populations in 1970 with the Program for the Interiorization of Health and Sanitation Actions in the Northeast (Piass) (Brazil 1976) .

After the International Conference on Primary Health Care, in 1978 in the city of Alma Ata, the concepts of health education, basic sanitation, maternal and child program, prevention and health promotion (WHO 1978) were highlighted . Integrated Health Actions (AIS) emerged in 1980 to strengthen comprehensive actions through a unified and decentralized system (Mendes 2015).

But it is in 1988, with the birth of the Unified Health System (SUS) that PHC becomes the main contact of the population with the System (Mendes 2015). The Family Health Program, implemented in 1994 by the Ministry of Health, proposed reorganization of the health system and the health work process, advocating assistance with collective health actions, serving people at all stages of the life cycle with varying demands and nonspecific that do not always fit into standards (WHO 1978) . The PSF was consolidated as a Family Health Strategy (ESF) in Ordinance No. 648, of March 28, 2006 issued by the government. The ordinance approves the National Primary Care Policy (PNAB), defines and characterizes the Primary Care guidelines and the FHS in its scope, updated and renewed in new editions in the years 2011 and 2017 (Brazil 2017).

The FHS and its continuous care become an essential part for the reaffirmation and execution of the SUS principles: universality, equity and integrality (Brasília 2000). Thus, it considers health as a right to all people without exceptions, to be a whole with distinct and unique needs (Brazil 2017; Brasília 2000).

In Brazil, the AA implantation experiences are more recent, starting in 2015, being experienced by teams in specific municipalities, therefore, it differs from the Canadian experience, in which it is more consolidated.

The studies presented the experiences of three family health units with the implementation of AA in two cities in the state of São Paulo (Souza 2019; Pires 2019; Leal 2015).

The implementation was planned, with the teams trained for the new model. Team meetings were used, with literature reviews, discussions of the themes and visits to the unit with the AA already in place. $(21,22,23)$ In addition, a unit evaluation process designed for users was developed (Souza 2019).

The proposed agenda varied between studies, one was $80 \%$ for open agenda and $20 \%$ reserved for appointments (21), another was $90 \%$ and 10\% (Pires 2019), and another carried out another open agenda experiment with two periods per week for appointments (Leal 2015). In order to make this possible, the teams created strategies such as a service flowchart based on the menu of activities developed in the unit's waiting room, a new service flow and dissemination to the population of the new model (Souza 2019; Pires 2019; Leal 2015).

When evaluating the implantation of AA, they listed some positive points, such as the greater resolution of acute complaints, which absorbed the spontaneous demand consultations, since the service is qualified and performed on the same day as the patient's search, facilitating access and reducing the number of visits. waiting time and consequently absences. It also corroborated for the strengthening of the bond between the team and the patients. (Souza 2019; Pires 2019; Leal 2015)

A study showed a decrease in the percentage of absences from $13.57 \%$ to $4.20 \%$ in two years, in addition to the number of medical visits that almost doubled, from 221 to 428, and an increase in the number of referrals from 9 to 41 . It highlights It is 
said that in 2015, there were 1,221 days of waiting for 98 calls, while in 2017 there were 33 days of waiting for 98 calls. (Pires 2019)

However, the experiences emphasize challenges to be overcome, such as the need to expand and improve the menu of activities, the efficient active search for patients belonging to priority groups, the disproportion between the offer of staff vacancies and the demand of the population, in addition to the delay in providing care in other points of the care network, which induces the return to the unit while waiting for the referral vacancy. (Souza 2019; Leal 2015)

With the implementation of the AA, the improvement of patient satisfaction and the optimization of the work process of the family health teams stood out.

In both countries, better results were evidenced in the implementation of AA with the effective participation and training of health teams, forming a work process that is adjustable to the needs of the population and the ability to serve the teams. Teams active in their work process develop a continuous flow of service evaluation, adapting to the demands and offering more effective activities to the population (Rocha 2016).

AA stands out as the most promising when balancing capacity and demand, with adequate physical structure and teams, both in the international scenario and in the experiences in Brazilian municipalities, improving the quality of PHC (Rocha 2016; Vidal 2019).

\section{Conclusion}

The Advanced Access model stands out as a possibility for organizing agendas, and both its implementation and its success must consider the history and context of PHC in each health unit and country in which it operates.

In Primary Health Care, care must be provided as efficiently and accessible as possible to the population, which means that its context, territory and profile must be considered. Advanced Access is a strategy to improve the population's access to health care. This study shows the context and reality of Advanced Access in 2 countries, so that it is possible to compare them and adapt strategies that fit both to the point of benefiting Access and care.

As a suggestion for future work, studies such as this one are needed that provide a scientific basis for AA and its implementation in a more practical way, highlighting its benefits and challenges. Studies that detail the AA in its practice and discuss the challenges and needs can equip other units to study it and consider its implementation, with a view to expanding access to health and the qualification of care in Primary Care.

Thus, according to each Unit and its particularities, it would be possible to identify challenges for the implementation of AA and develop interventions that seek to overcome these challenges, such as training, lectures and public policies that benefit the model.

\section{References}

Belo Horizonte. (2010). It would make HP. Care Model and Primary Health Care. NESCON / UFMG - Specialization Course in Primary Care in Family Health (2a ed.), 67p

Brandão, J. R. M. (2019). Primary health care in Canada: reality and current challenges. Cad. Public Health 2018.35 (J): e00178217.

Brasília. (2000). Ministry of Health (BR). Unified Health System (SUS): principles and achievements. Brasília: Executive Secretariat; Ministry of Health. 44 p. Brazil. (2000). Decree No. 78,307, of August 24, 1976. Approves the Program for the Interiorization of Health and Sanitation Actions in the Northeast and provides other measures. Official Gazette of the Union.

Brazil. (2017). Ministry of Health. Ordinance No. 2,436, of September 21, 2017. Approves the National Primary Care Policy, establishing the revision of guidelines for the organization of Primary Care, within the scope of the Unified Health System (SUS). Brasília, DF: Ministry of Health.

Breton, M., Maillet, L., Paré, I., Malham, S. A. \& Touati, N. (2016). Int J Health Plann Mgmt. Published online in Wiley Online Library (wileyonlinelibrary.com) 10.1002/hpm.2380. 
Filho, L. A. S. P., Azevedo-Marques, J. M., Duarte, N. S. M. \& Moscovici, L. (2019). Advanced Access in a Family Health Unit in the interior of the state of São Paulo: an experience report. Health Debate/Rio de Janeiro, 43(121), 605-613.

Fournier, J., Rainville, A., Ingram, J. \& Heale, R. (2015). Implementation of an Advanced Access Scheduling System in Primary Healthcare: One Clinic's Experience. Healthcare Quarterly 18(1).

Gonçalves, G. P., Knupp, L. L., Corrêa, R. D. \& Mendonça, L. G. (2018). Advanced Access: A 7-Step Practical Guide. Advanced Access Workshop, Belo Horizonte.

Leal, A. E. B., Watanabe, B. T., Bezerra, C. W., Palluello, R. A. S., Gyuricza, J. V., Rewa, T., Guimarães, A. C. B., Storch, B. C. \& Áurea, R. G. (2015). Advanced Access: A Path to Integrality in Primary Care São Paulo. SMS.

Malham, S.A., Nassera, T., Maillet, L., Gaboury, I., Loignon, C. \& Breton, M. (2017). What Are the Factors Influencing Implementation of Advanced Access in Family Medicine Units? A Cross-Case Comparison of Four Early Adopters in Quebec. International Journal of Family Medicine. Volume 2017, Article ID 1595406, 15 pages https://doi.org/10.1155/2017/1595406.

Mendes, E. V. (2015). The social construction of primary health care. Brasília: National Council of Health Secretaries - CONASS.

Murray, M. \& Tantau, C. (2000). Same-day appointments: exploding the access paradigm. Fam Pract Manag; 7: 45-50.

PAHO / WHO. (1978). Alma-Ata Declaration. International Conference on Primary Health Care.

Renovato, R. D. \& Bagnato, M. H. S. (2010). The special public health service. Educar em Revista, Curitiba, Brazil, Editora UFPR n. special 2, p. 277-290.

Rocha, S. A., Bocchi, S. C. M., \& Godoy, M. F. (2020). Access to primary health care: an integrative review. Physis. 26(1): 87-111. http://www.scielo.br/scielo.php?script=sci_arttext\&pid=S0103-73312016000100087\&lng=en. http://dx.doi.org/10.1590/S0103-73312016000100007.

Santos, C. M. C., Pimenta, C. A. M., \& Nobre, M. R. C. (2007). The PICO strategy for the construction of the research question and search for evidence. Latin American Journal of Nursing , 15(3), 508-11.

Santos, J. C., \& Melo, W. (2018). Comparative Health Study: Models of Primary Health Care in Brazil, Canada and Cuba. Interinstitutional Journal of Psychology, 11 (1), 79-98.

Souza, L. F., Rossi, F. M., Ogera, A. F., Borges, M. A., Galdino, S. S., Souza, P. F. Z. B., Ramos, A., Goto, C. I., Silva, L. V. L., Francisco, M. A. G., Souza, R. C., Nascimento, M. A. O., Colosio, A. M. N. \& Bolieiro, S. V. M. (2019). Advanced Access: accumulated experiences in one year of implementation PMSP/ Municipal Secretary of Health of São Paulo.

Souza, M. T., Silva, M. D. \& Carvalho, R. (2010). Integrative review: what it is and how to do it. Einstein 8(1), 102-6.

Starfield, B. (2002). Primary Care: balance between health, service and technology needs. Brasília: UNESCO, Ministry of Health, 726 p.

Vidal, T. B. \& Mengue, S. S. (2012). Advanced Access and its relationship with the number of medical care in Primary Health Care. Federal University of Rio Grande do Sul UFRGS.

Vidal, T. B., Rocha, S. A., Harzheim, E., Hauser, L. \& Tesser, C. D. (2019). Scheduling models and quality of primary care: a multilevel cross-sectional study. Rev. Public Health http://www.scielo.br/scielo.php?script=sci_arttext\&pid=S0034-89102019000100233\&lng=en.

Wollmann, A. (2014). New possibilities for organizing Access and the Agenda in Primary Health Care. Municipal Health Secretariat of Curitiba.

Would, L. R. \& Alves, C. A. (2015). Care in primary health care: preliminaries of a comparative study Brazil/Canada. Soc. 24(1), 72-85. 